\title{
A feminine style of management in the contemporary business world
}

\author{
Irina Nikulina ${ }^{1, a}$, Igor Khomenko ${ }^{1}$, Anna Sediakina ${ }^{1}$, and Viktor Kanov ${ }^{2}$ \\ ${ }^{1}$ Tomsk Polytechnic University, 634050 Lenin Avenue, 30, Tomsk, Russia \\ ${ }^{2}$ Tomsk State University, 634050 Lenin Avenue, 36, Tomsk, Russia
}

\begin{abstract}
The main goal of the article is to provide the insight on the gender management in connection with contemporary management. There have been wide ranges of scientific discussions regarding the question of a specific management style that women use in the business practice. A traditional approach indicates that there is no such way of managing an organization as a feminine management style. The traditional approach emphasise that women tend to use the men's leading style with slight adjustments such as human relations and intuition. A new approach to management indicates that the women's management style is a reality of any contemporary organization. Hence, a distinct approach to the feminine style of management and its influence on an organization will be explored in this article. Also specific guidelines that women managers can use to become successful in the administrative positions will be described. Data used in the article include the Russian Federation and European statistics on women occupying administrative positions.
\end{abstract}

\section{Introduction}

In modern humanities a traditional concept of "gender" is used to refer to various physiological characteristics of individuals, on the basis of which individuals are differentiated into male or female. Gender is considered to be the basic foundation of human psychological and social differences between women and men. However, with the development of science, scientists have begun to study distinctive social roles of men and women, the diversity of their activities, the differences in behaviour and emotional perception of reality. The notion "gender" means a set of attributes that determine the social behaviour of women and men and the relationships between them.

Concepts and methodological backgrounds of contemporary management are in a constant change, they mutually complement each other, and they are disposed to transformation. And it is very important for practicing managers at all levels to study various phenomena of a new era of management and postmodernism for an appropriate response to arising organizational problems. Ways and methods of solving the problems of modern management depend directly on the practical art of management, or, in other words, the management style. There are well-known and widely accepted classical management styles. In addition to existing styles, the new era brings innovative

\footnotetext{
$\overline{{ }^{a} \text { Corresponding author: nie@tpu.ru }}$
}

understanding of male and female styles or feminine and masculine styles of management.

Understanding a feminine or woman's style of management is important for top-management practice, and involves a new methodological direction of modern management - gender management. Its existence and importance cannot be denied.

The influence of diverse cultures and national features, as well as various consequences of the globalization process, and integration in the environment of management methodology functioning contributes into the arrival of the new, modified directions and into the development of management theory and practice. These directions include new types of management, such as network, creative, cognitive, communication and other types of management.

\section{Gender management}

Gender management is standing in the same line with the newly arrived ones. It was originated just at the end of the last century. Since then, it has become a research target for international and domestic scientists. They started learning more about various gender aspects of economics and management. One of the reasons for the increasing interest in gender management was the postindustrial society itself. It has changed the nature of the relationship between the genders throughout the twenties century. Being under the influence of the post-feminist 
psychology the hierarchy of patriarchate has gradually faded away, by equalizing legal rights and opportunities for men and women in business, in private life and in organizational management.

To provide the support to our thoughts we will address the international source: The Convention on the Elimination of all Forms of Discrimination against Women (CEDAW) [1]. This is an international treaty adopted in 1979 by the United Nations General Assembly, which encourages all countries to introduce the quotas of up to 30 per cent for women, occupying senior positions. Many European countries, mainly the Scandinavian ones, have managed to overcome the quota. For example, in 2012 the representation of women, occupying different positions in legislature was 44 per cent in Sweden, 42.5 per cent in Finland, 40.7 per cent in the Netherlands, 39.7 per cent in Iceland, and, 39.6 per cent in Norway, 39.1 per cent in Denmark [2]. In this respect, Russia is also not far behind Europe. Data of 2013 reveal that among the governmental positions by category almost 561.1 thousand positions were occupied by women, and 225.3 thousand positions were occupied by men. Distribution of managerial and administrative positions among them was also peculiar: almost 78 thousand managerial positions were occupied by women, and only 48.9 thousand positions were occupied by men [3].

Hence, the facts and the figures persistently indicate that the gender management does exist, and the role and the place of women are currently in the leading positions. Therefore, there is a necessity to study the characteristics of the feminine management style, and it is highly essential for further development of management.

It is important to indicate, that the traditional approach to management identifies a manager as a person, not interfering into the organizational processes, people and resources, but only as a specialist that performs certain functions defined in the job description of an organization. The functions themselves are often not relevant to the understanding of the goals and objectives determined by the manager. Whereas the work results of a manager are equal to the performance and the achievements of her/his team. A good manager should be able to organize and inspire subordinates, make them move to the right direction of effective collaboration by taking management decisions. Each and every manager should remember that people working in the organization are the most limited and valuable resource [4]. However, class and gender prejudices following as a halo of the past centuries, still exist in Russia. Men express doubts and bias towards women in management. From this point, a female manager has to intensify her efforts and her professional capabilities to show greater results than men do. Nevertheless, women managers are inherent to utilize innovative approaches to management. These approaches, described below, help a woman manager to lead in the profession.

\subsection{Approaches to female leading}

The female manager does not seek out enemies, but tries to benefit from opposition. Enemies in the organization, often without realizing it, create glory for those perceived as opponents or enemies. Such perception of opponents allows women to be more careful in business and in managing people, and also helps them to adjust their professional and personal weaknesses. Competitors require from businesswomen to constantly and actively seek new compromise and cooperation, to be crafty. If the internal organizational fight is still imminent, the woman leads it as honestly and decently as possible, because not only victory is important but also the means. A woman does not accept the deceitful victories.

The woman manager is able to attract her friends to business, even though everyone knows that a modern management slogan sounds like: do not combine friendship with business. However, woman is able to get from friends not only fun, but also favors. A woman manager is able to find assistants, patrons, agents and consumers of her business herself within her own circle of friends. The woman manager is in her constant selfactualization process. She treats herself and her retinue critically. This position allows her to improve her temper, to root out her biases and hold high opinions. It is connected with the fact that woman is required to dominate her age and appearance. And, thinking of her appearance, woman unwittingly pays attention to inner content of her spiritual and professional qualities.

The female manager makes a decision and implements it only when she has no doubt in future success.

This approach is associated with low self-confidence of the woman manager, her constant doubts in the decision. She would better refrain from the actions if they do not guarantee the success of her activity. However, her prudence in this case would not allow ambiguity. Intuitive by nature, a woman is moving to ensure that the choice is negotiated and combined with one true way of actions. A woman has remarkable prudence in understanding of good and reasonable.

The female manager is able to combine the subject area with a variety of its existence if she realizes that changes encourage interest in this subject area. Perception of the diversity in the world helps a woman in managing people, because all people are different. Skills to understand people, to know their personalities and to perceive their moods help a woman to create a team of like-minded people.

The female manager, while her career is in the stage of growth, is not resting and she is always mindful of the crises cycles and of the approaching bifurcation points. Hence, she constantly needs to have her strength and resources in reserve to combat the future crisis periods. Amassing instead of wasting is the feature that characterizes a woman manager best of all, even the key knowledge she keeps in storage. In business, it is always better to have two or three anti-crisis resources than one. Thus, we can say that the woman is always ready to be an efficient crisis manager, not even realizing it.

The female manager never steps in business adventures, associated with the rivalry, which brings out revenge, intrigue, takes time from the business. She 
keeps in mind that time today is a limited resource for management.

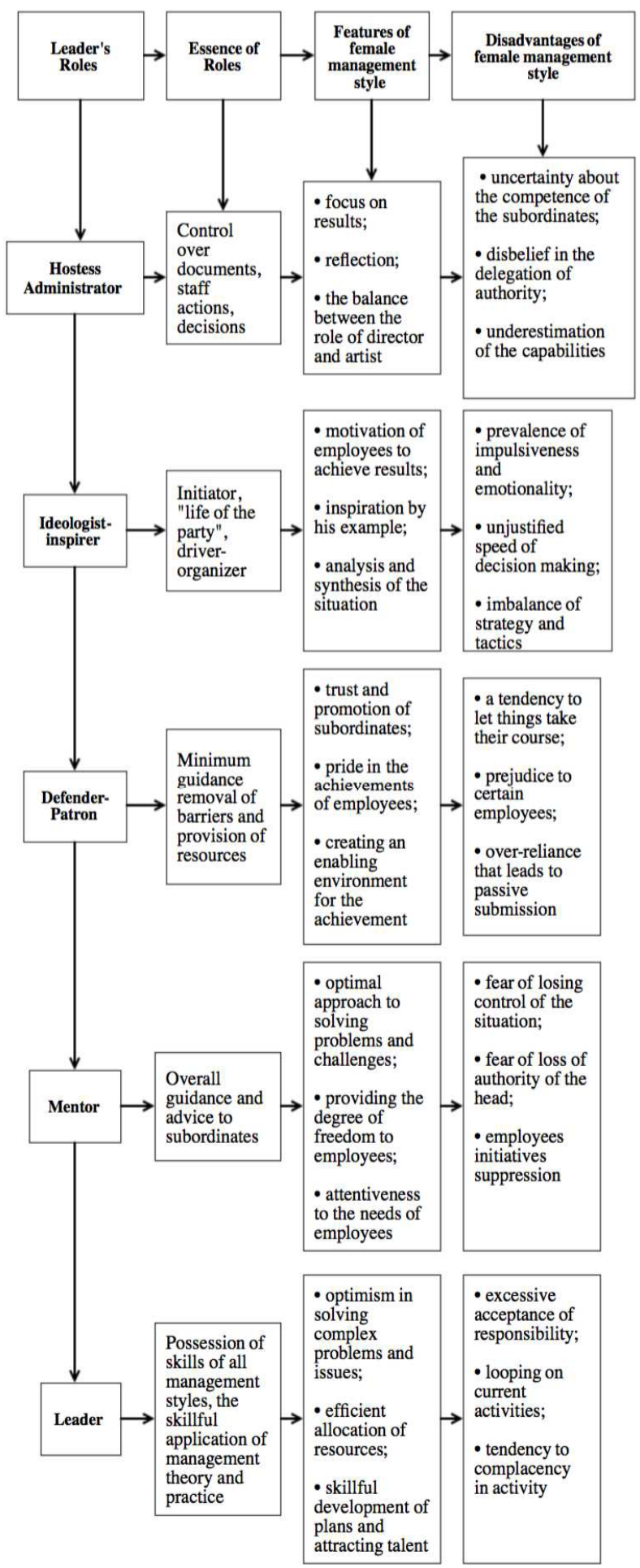

Fig. 1. Women's role-based management styles.

To successfully manage a team, women leaders need to learn a lot, and most importantly to remember that in order to be successful it is necessary be able to create personal professional competence, to join and develop cooperation, to be able to appreciate both personal and shared achievements of the team. The woman-manager is constantly learning to play as a team and develop an interest in frequent changes in life and professional roles: a daughter, a wife, a mother, a consumer, a builder, an employee, a manager. She has several leader roles, some of which are shown in Figure 1.

And despite the fact that the man controls the intellect and strength, relying on a strategy, and the woman does it by cunning and agility, giving more time to current affairs - together they complement each other in the art of management. That is why in science and practice of management male and female leaders both take notable places. Moreover, teams of subordinates should not be of one gender.

In conclusion, we will explore six rules by an American psychologist, who explains how to survive successfully for women in the world of male business (Table 1) [5].

Table 1. M. Andrien's survival rules for women.

\begin{tabular}{|c|c|}
\hline Rule & Characteristics \\
\hline $\begin{array}{l}\text { Rule 1: Reveal } \\
\text { your } \\
\text { competences }\end{array}$ & $\begin{array}{l}\text { 1) Act as if you are aware of what to do. } \\
\text { Even if you are not completely certain in } \\
\text { your power. } \\
\text { 2) Being modest might be a good } \\
\text { feature, but it would not lead you to } \\
\text { success. } \\
\text { 3) Seek help only if you have no other } \\
\text { options. } \\
\text { 4) Advertise and promote your } \\
\text { achievements and skills. } \\
\text { 5) Do not show off your mistakes }\end{array}$ \\
\hline $\begin{array}{l}\text { Rule 2: Show } \\
\text { your strength }\end{array}$ & $\begin{array}{l}\text { 1) Always try to keep the actions under } \\
\text { control. } \\
\text { 2) Do not overemphasis your } \\
\text { dependence on your supervisor. It is } \\
\text { always better to say: "Let's get back to } \\
\text { this question later" than "I have to } \\
\text { consult my boss" } \\
\text { 3) Try to keep your temper under } \\
\text { control, even if your opponent is trying } \\
\text { to manipulate you. } \\
\text { 4) Do not complain if something goes } \\
\text { wrong. "If life gives you lemons, } \\
\text { squeeze lemonade" } \\
\text { 5) Use some humor. }\end{array}$ \\
\hline $\begin{array}{l}\text { Rule 3: Keep } \\
\text { fighting till the } \\
\text { end, even if the } \\
\text { game does not } \\
\text { bring positive } \\
\text { outcomes }\end{array}$ & $\begin{array}{l}\text { 1) People must be aware of your area of } \\
\text { expertise. } \\
\text { 2) Sometimes it would not do harm to } \\
\text { exaggerate your achievements. }\end{array}$ \\
\hline $\begin{array}{l}\text { Rule 4: Do not } \\
\text { take the game } \\
\text { too seriously }\end{array}$ & $\begin{array}{l}\text { 1) Do not overreact when opponents } \\
\text { and colleagues make comments. } \\
\text { 2) Reveal your temper only when time } \\
\text { comes. }\end{array}$ \\
\hline $\begin{array}{l}\text { Rule 5: Fight is } \\
\text { an inevitable part } \\
\text { of the game }\end{array}$ & $\begin{array}{l}\text { 1) Fight must be honest. } \\
\text { 2) Avoid being too invasive or too } \\
\text { passive. Target your opponent weakness. } \\
\text { 3) Always know when to stop if the } \\
\text { goal has been reached. } \\
\text { 4) Learn how to win and to lose. }\end{array}$ \\
\hline $\begin{array}{l}\text { Rule 6: } \\
\text { You are a team } \\
\text { player }\end{array}$ & $\begin{array}{l}\text { 1) Teammates wear the uniform. } \\
\text { 2) Teammates support each other. } \\
\text { 3) Be loyal to your team. }\end{array}$ \\
\hline
\end{tabular}


4) Interest of your team are prevailing.

5) Always show 100 per cent of you strength.

As we can see this advice could be used for administrative, staff of all levels.

\subsection{Negative trends in the women's career development}

Adaptation period for woman on managerial position takes longer compared to male manger. The major reason for such organization deviation is the rejection of the followers. Resistance and negative attitudes of male subordinates make first days in the position of a manager very challenging for a woman. Female part of the organization also provides no support or gender solidarity to a newly appointed manager due to envy, intrigue and rivalry with the woman-manager.

Sometimes female managers have to face unjustified and non-constructive criticism, simply because they are women.

Women leaders are beginning to be considered only with the recognition of their credibility as managers, but not with respect to their abilities and individual achievements of being women in general.

A woman manager in most countries of the world has to face uneven attitude in payment distribution. Statistics shows that the payment of woman manager is significantly lower than of men managers.

Evaluation of personal contribution of women managers to the company success is often underestimated by the administration.

A female manager tends to high level self-analysis and because of the propensity to self-criticism, is experiencing dissatisfaction with her professional growth, often does not see her promotion prospects in the nearest future.

Women managers have to combine two roles in the same time: prosperous manager and good wife and mother. In the implementation of professional skills and providing career she has difficulty in reconciling family responsibilities. This double burden on women negatively affects her emotional and psychological mood and reduces the efficiency of work.

Managers of many firms restrict employment of women of reproductive age due to the need to provide social benefits and rights associated with the birth of the child and the subsequent changes in her status.

In some countries in recent years the practice of management relations became more challenging: moral harassment (mobbing) became part of organizational routine. It is expressed in a negative impact on women by male supervisor or colleague in acts of violence or harassment. The reasons are varied from the elimination of a competitor, and forcing to the dismissal, to increasing the authority of the head and of sexual harassment.

Studies of science and practice of management are based on men's style of management and men's standards of professional conduct. And companies tend to compare men's management style to the behavior of women. Female professional abilities and her personal characteristics, gender-specific approaches to management have recently became an object for research. However, it is rather an exception from the standard rules.

\section{Conclusion}

Men and women as biological opposites support the world balance and generate harmony. Their approaches to life complement each other. The same we can see in any sphere of life, including business. The interaction of two management styles, female and male, in the business brings the wisdom. It is highly important for manager to practice the right approach that will correlate with his or her personality.

\section{References}

1. UN Convention on the Elimination of All Forms of Discrimination Against Women, Access mode: https://en.wikisource.org/wiki/Convention on the Elimination of All_Forms of Discrimination_Agai nst Women (Access date: 21.09.2015) (2014)

2. The report of Inter-Parliamentary Union (IPU), Access mode: http://www.ipu.org/2014 (Access date: 21.09 .2015$)$ (2014)

3. L. Ageeva, G. Ljubova, T. Melnikova, etc., Stat. Rep. Rosstat (2014)

4. P. Drucker, Management tasks of the 21st century (EID, Williams, 2002)

5. M. Andrien, Games that men play (St. Petersburg, Piter, 2001)

6. I. Nikulina, I. Khomenko, Social and Behavioral Sciences, 166, (2015)

7. O.V. Shevtsova EMIT, 3, (2014)

8. O. Nikitina, Cons. Acc., 6, (2007)

9. M.A. Shumkova, Bull. of Ud. Un. Press, 3-1, (2009)

10. T.P. Khokhlova, Man. in Rus. \& abr., 2, (2001)

11. Research OECD, Access mode: http://www.pwc.ru/ru/boardsurvey/index.jhtml (Access date: 21.09.2015) (2012)

12. L.A. Nazarova, ZForbes, 1, (2012)

13. E.Z. Veras, Product Innovation Management, Wuhan, (2010)

14. S. Hoogendoorn, H. Oosterbeek, M. van Praag, $M S$, 59 (7), (2013)

15. I.E. Nikulina, Probl. of Econ, 1 (10), (2013)

16. E.B. Lenchuk, G.A. Vlaskin, Probl. of For, 5, (2010) 